\title{
The Different Types of Flaps in the Surgical Relations of the Third Impacted Molars-Literature Review
}

\section{Guillermo Blanco*, Dianorys Lora and Clovys Marzola}

Dentistry University Foundation, Hospital Heli Moreno Blanco, Brazil

\begin{abstract}
Third molars can present themselves completely and or partially retained and may be mucosal, submucosal, or completely retained within the jaws or jaw. The surgical technique includes an incision type, playing a key role in wound healing, presenting a series of incisions described over time, by different researchers and authors, in an attempt to minimize their impact, employ professional judgment one according to your needs and convenience.
\end{abstract}

Keywords: Third molar; Impaction; Flap design

\section{Introduction}

The impacted third molar surgery and/or partially impacted is the most common procedure in oral surgery and maxillofacial [1-18], ranging from therapeutic indications, previous history of infection [19-22] periodontal disease [23], pericoronitís [30-33],operating an inexplicable [34] pain associated with the third molar [35-36], pain, intractable caries prevention caries [37-43], tooth root resorption adjacent [35,44-46], orthodontic considerations incisor crowding lowers [47-52], prosthetic considerations [53], prevention and/or association of fractures mandibulars [14,54-58,61-65], prophylaxis [45], systemic considerations health [66-88], cysts and tumors [13,61,90,91], interference with orthognathic surgery or mandibular reconstruction [92] teeth to use transplants [93], teeth involved in the field of a tumor recession $[34,94]$, opposing teeth that serve no role in occlusion $[62,95]$.

The controversy in the treatment of third molars is oriented philosophical currents of professional interventionists who are in favour of prophylactic removal of third complete and/or partially impacted molars symptom -free gives some pathology, covered in the indications for avoid a number of complications, however there is no scientific evidence to affirm or deny that all these procedures promote health patient [91,97-99] .

Among the most common complications are; anxiety pre and postsurgical [100-101], pain, trismus, infection, dry socket [102-107], as a measure to prevent these risks and complications has been proposed that the surgical technique and surgeon experience are essential for the proper management of any complications [1,35].

Inside The surgical technique includes; flap design, technique of bone removal, tooth sectioning method, drain placement, intentional exposure of the socket and suture technique [108], try the incision, many authors have proposed different incisions[109-123] Figures 1-24, each of these has been given to ensure adequate access and decrease the side effects of the procedure such as, pain, trismus, swelling, dry socket and infection, reduce complications has been the purpose of the statements of many studies using these incisions.

Another major concern periodontal defect are likely to arise in the distal surface to 2 molar after the removal of impacted third molars, publications have reported frequency of periodontal disorders, agerelated tilt of the molar, visible surface plate 2 molar distal [124]. But these conflicting results have periodontal problems according to studies reported, while some report a decrease in bone height distal to 2 molar after extraction of impacted molar, others state that the height was increased after surgery, this height may be affected by the mere fact of raising a flap without osteotomy [125].
To Nageshwar, The incision should not be performed on bone defects, or cut the muscle or tendon, the incisions should not be very long, and they could influence the unfortunate consequences of extraction [123].

The flap design according Karaca et al., used during surgery for removal of impacted third molars prevents complications related to 2 molar periodontal status [125]. Suarez et al. believe that this design influences healing primary [122]. This prevents wound dehiscence and evaluated the suture technique to achieve this closure to Sanchis et al. [124], believe that primary closure avoids draining the socket and worse postoperative inflammation and pain, choose to place drains, obtaining a less postoperative painful [127].

The envelope flap according to Kirk et al., has an incidence of wound dehiscence, which could lead to a dry socket and postoperative

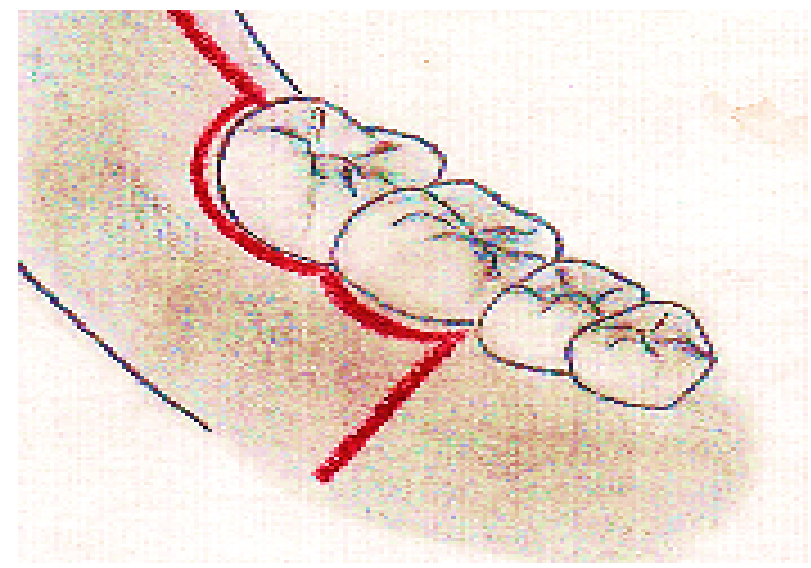

Figure 1: The design proposed by Mead, 1930, to the mandible incision.

*Corresponding author: Guillermo Blanco, Dentistry University Foundation, Hospital Heli Moreno Blanco, Goiânia, Goiás 74550-120, Brazil, Tel: 55-35999401646; Fax: 55-35-999401646; E-mail: guillobb@yahoo.com

Received September 24, 2016; Accepted March 27, 2017; Published March 31 2017

Citation: Blanco G, Lora D , Marzola C (2016) The Different Types of Flaps in the Surgical Relations of the Third Impacted Molars -Literature Review. Dentistry 7: 425. doi:10.4172/2161-1122.1000425

Copyright: $\odot 2016$ Blanco G, et al. This is an open-access article distributed under the terms of the Creative Commons Attribution License, which permits unrestricted use, distribution, and reproduction in any medium, provided the original author and source are credited. 


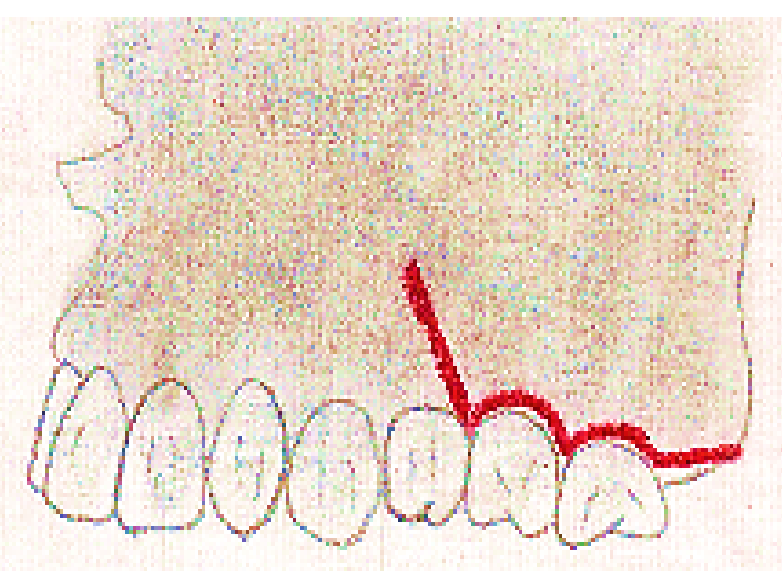

Figure 2: The design proposed by Mead, 1930 maxilla incision.

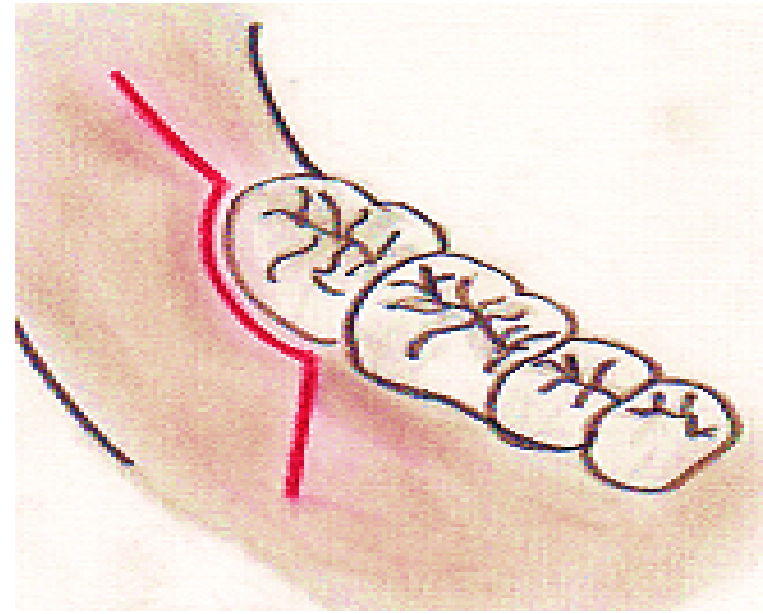

Figure 3: The design proposed by Cogswell, 1933 to the jaw incision.

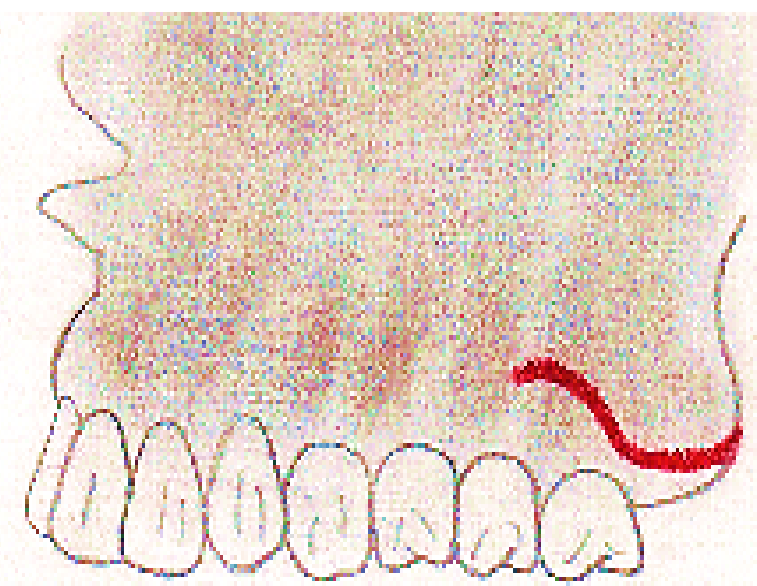

Figure 4: The design proposed by Avellanal, 1946 maxilla incision.

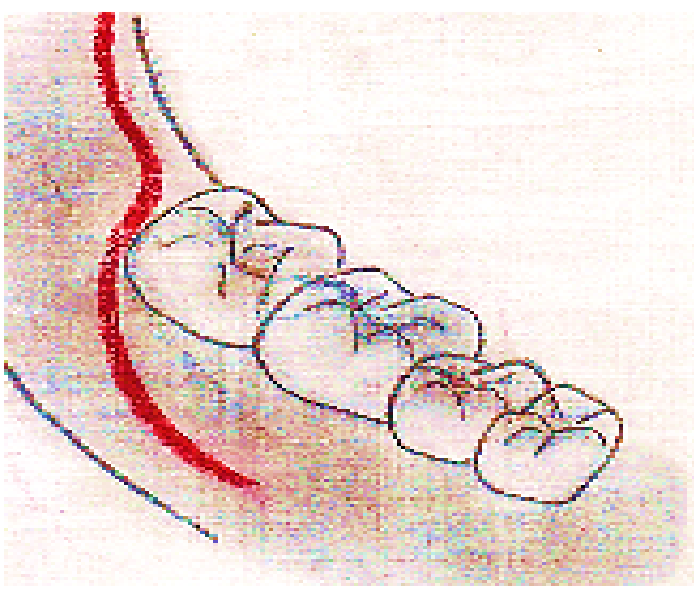

Figure 5: The design proposed by Avellanal, 1946 to the jaw incision.

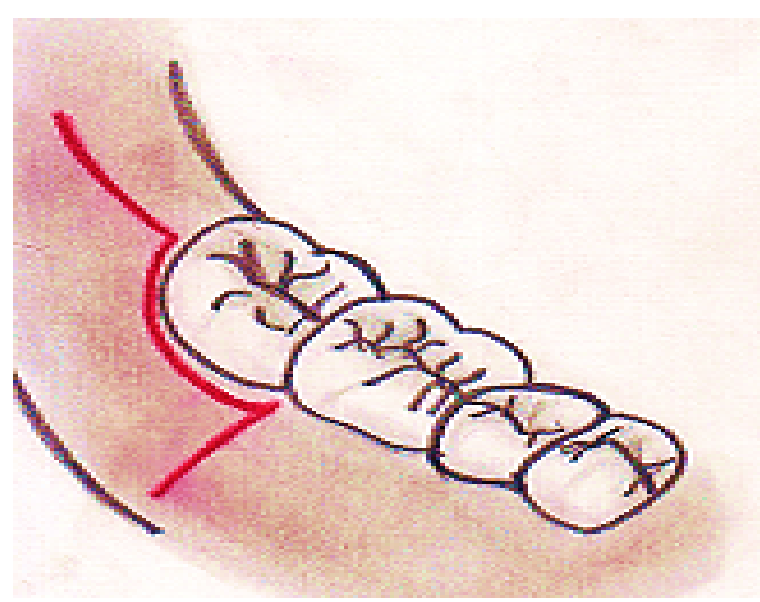

Figure 6: The design proposed by Ward, 1946 to the jaw incision.

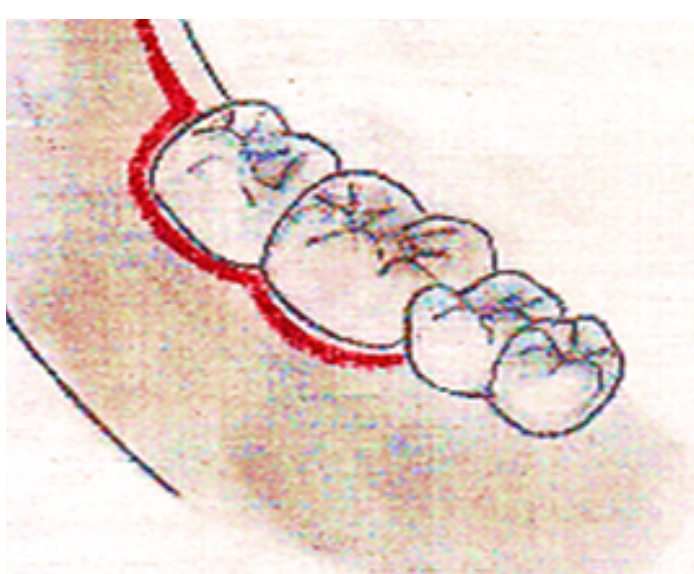

Figure 7: The design proposed by Maurel, 1959 to the jaw incision. 


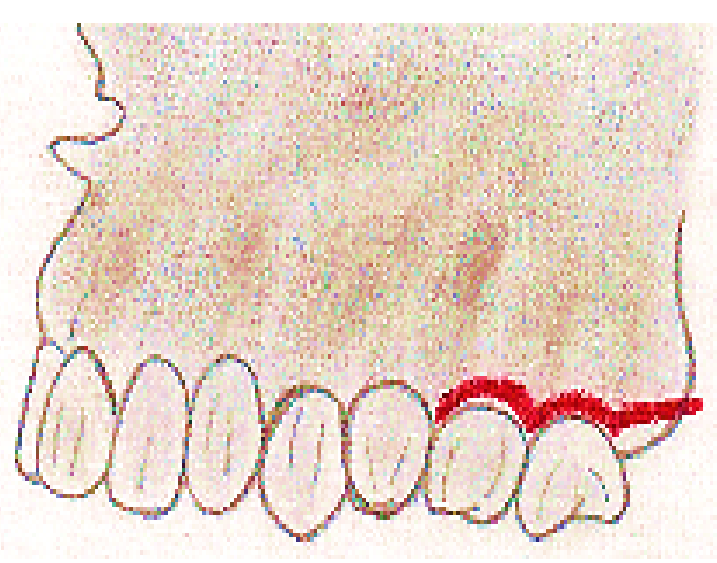

Figure 8: The design proposed by Maurel, 1959 maxilla incision.

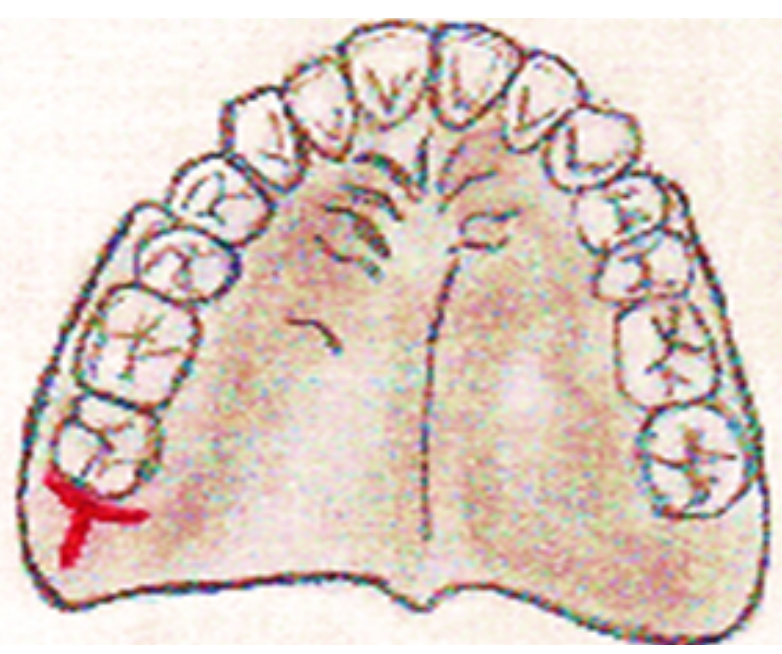

Figure 9: The design proposed by Kruger, 1959 to the jaw incision.

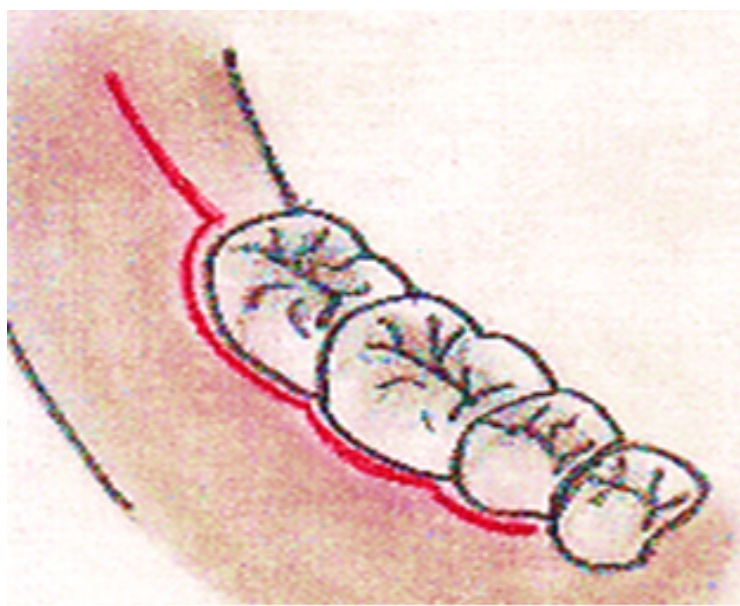

Figure 10: The design proposed by Ries Centeno, 1960 maxilla incision.

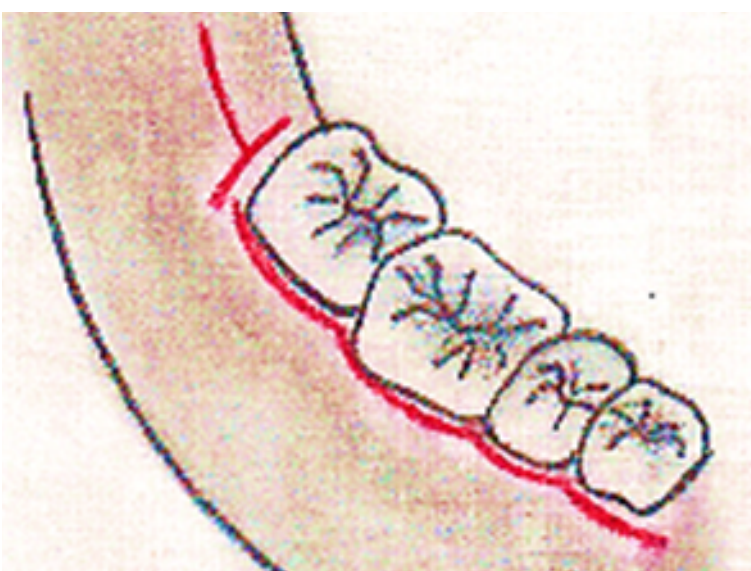

Figure 11: The design proposed by Ries Centeno, 1960, to the mandible incision

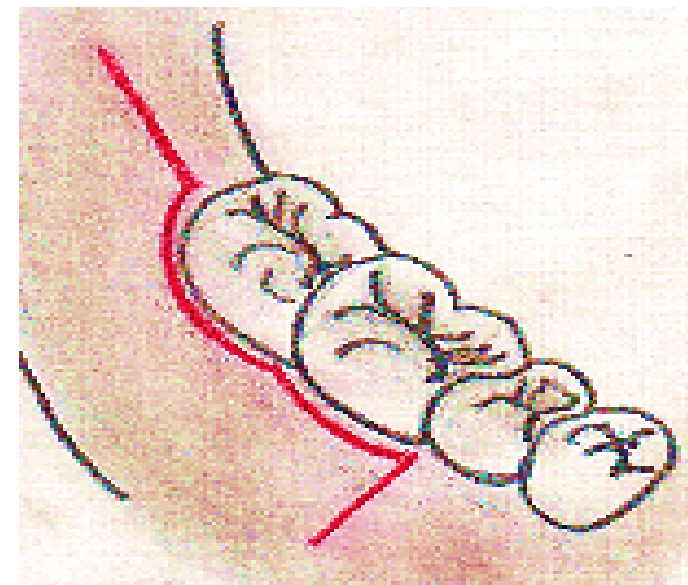

Figure 12: The design proposed by Szymd, 1971 for the mandible incision.

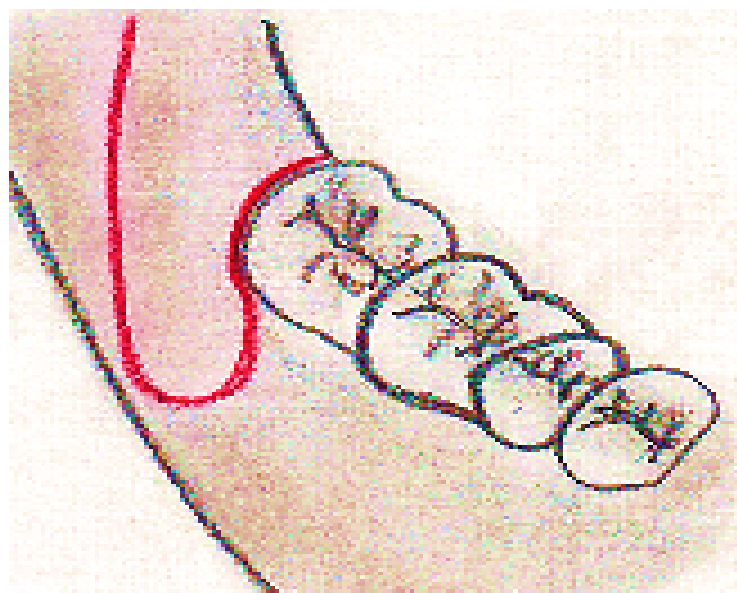

Figure 13: The design proposed by Berwick, 1971 for the mandible incision. 


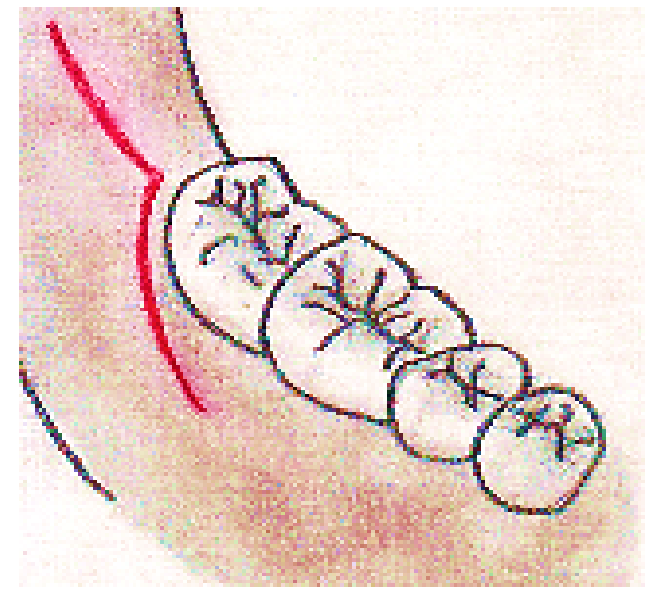

Figure 14: The design proposed by Howe, 1971 for the mandible incision.

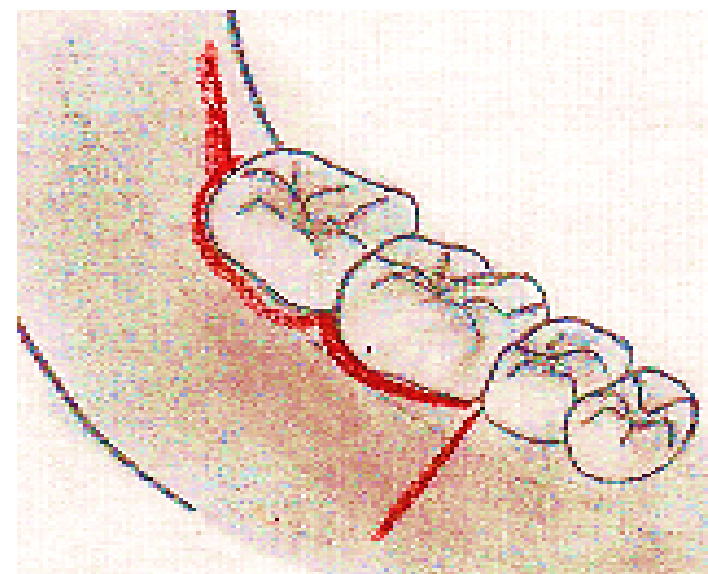

Figure 15: The design proposed by Lotter, 1984, to the mandible incision

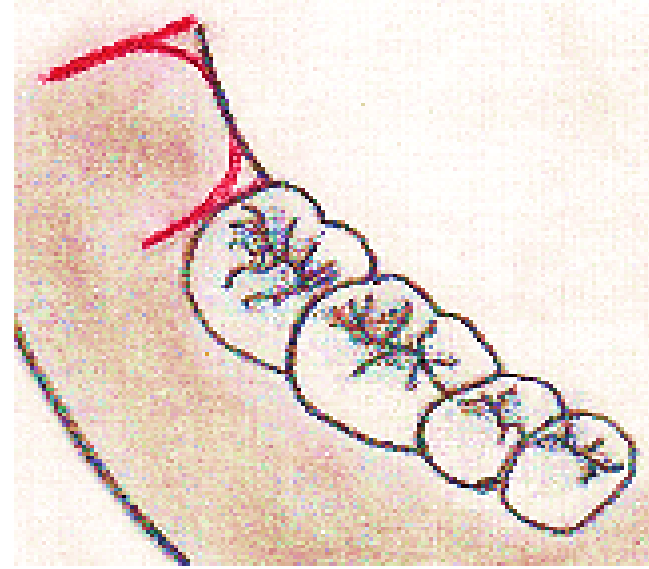

Figure 16: The design proposed by Berzaghi, 1989, to the mandible incision.

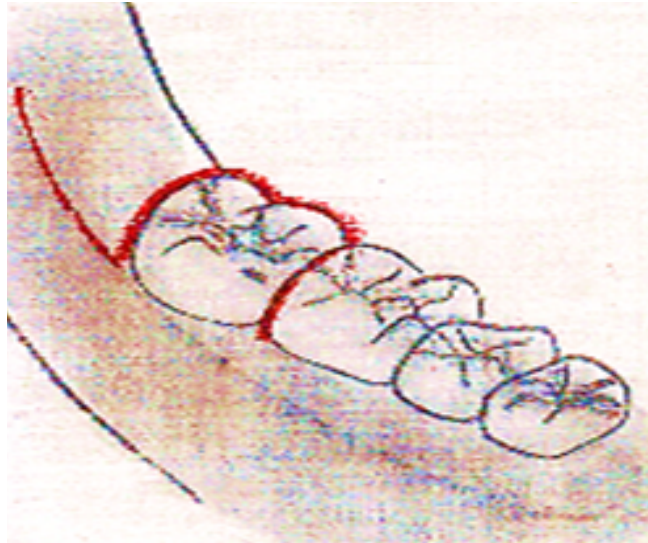

Figure 17: The design proposed by Stevão et al, 1998 to the jaw incision.

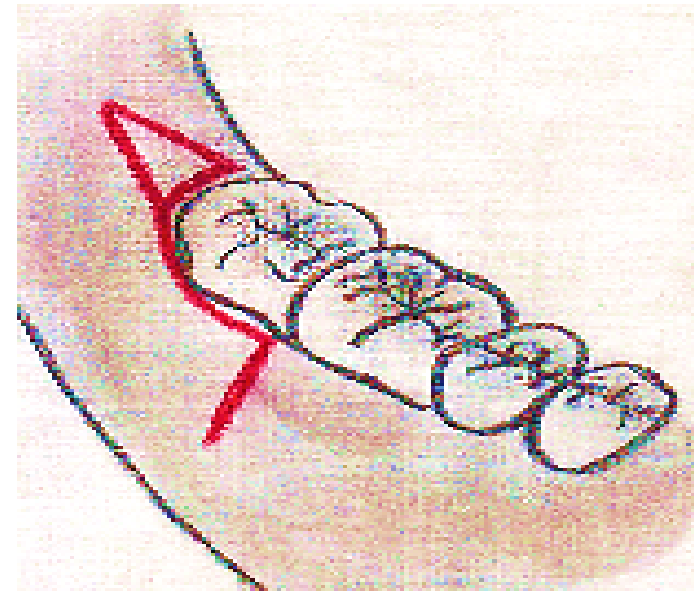

Figure 18: The design proposed by Saad Neto, 2000 to the jaw incision.

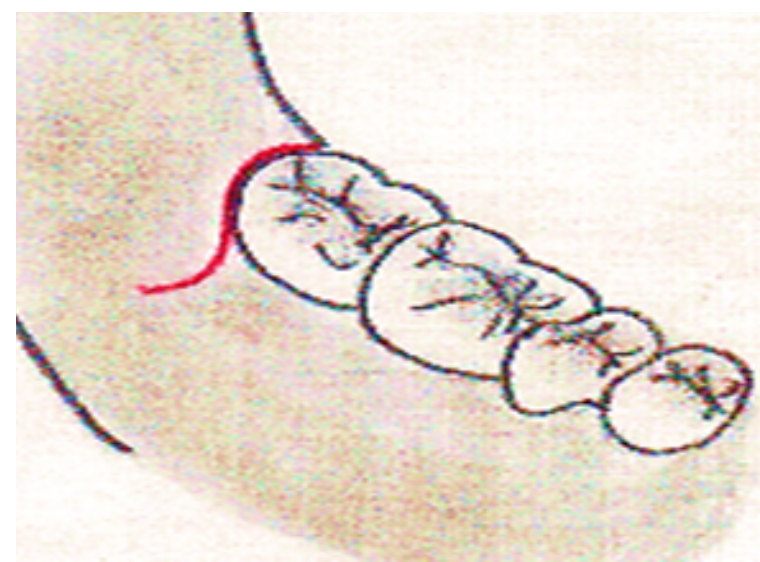

Figure 19: The design proposed by Nageshwar, 2002 to the jaw incision. 


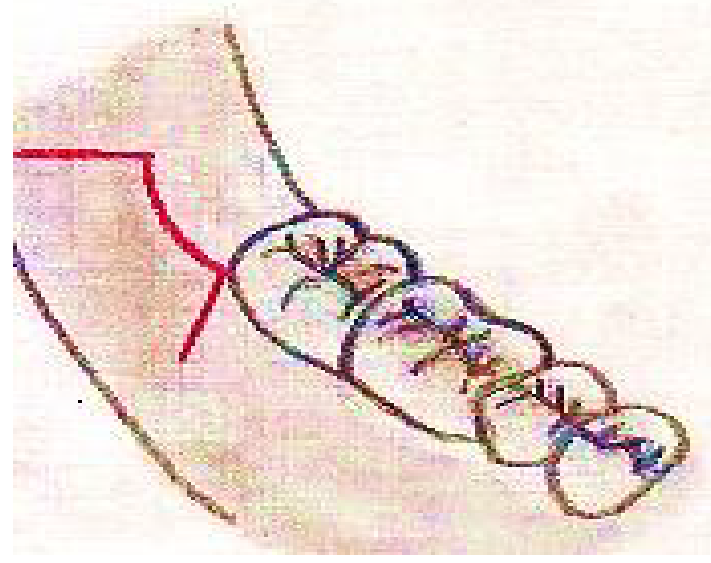

Figure 20: The design proposed by Suarez, 2003 to the jaw incision.

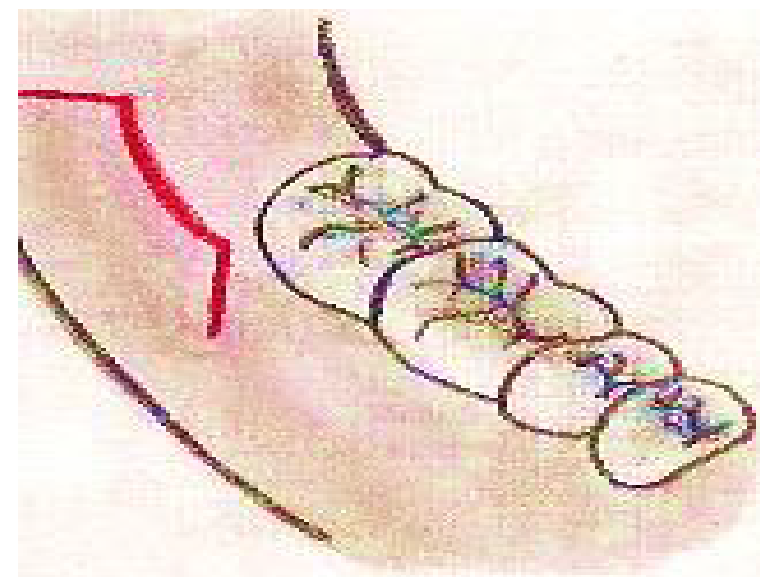

Figure 21: The design proposed by Suarez, 2003 to the jaw incision.

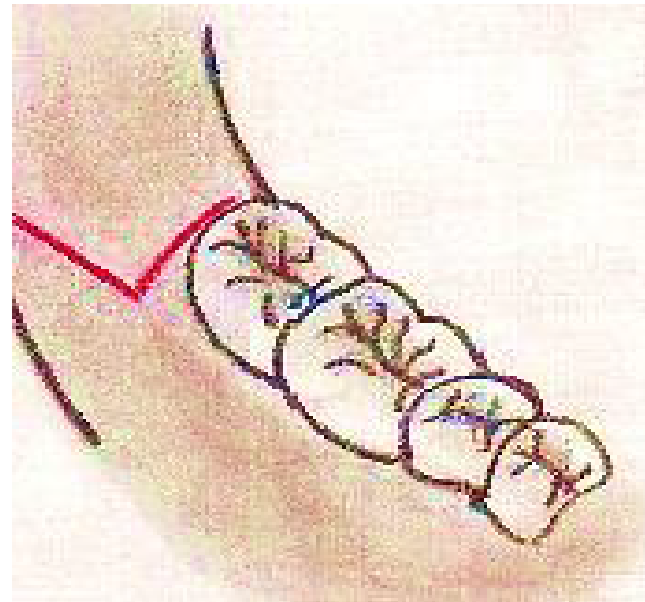

Figure 22: The design proposed by Heitz et al, 2003 to the jaw incision.

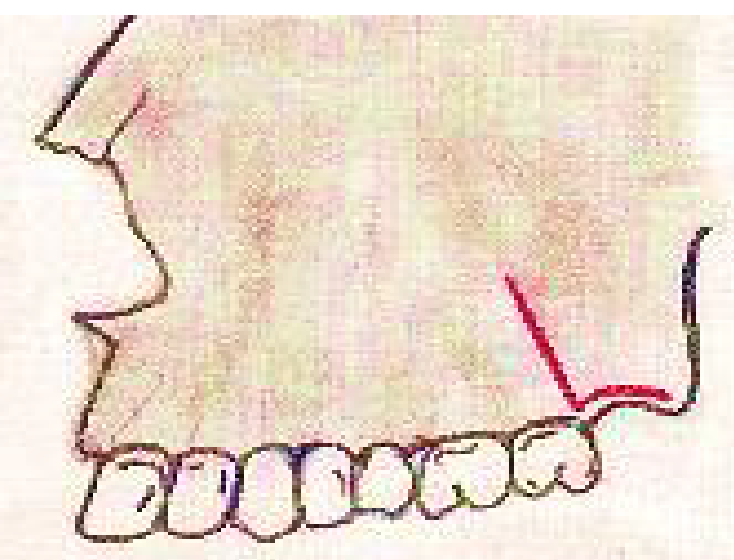

Figure 23: The design of the triangular incision advocated for the maxilla.

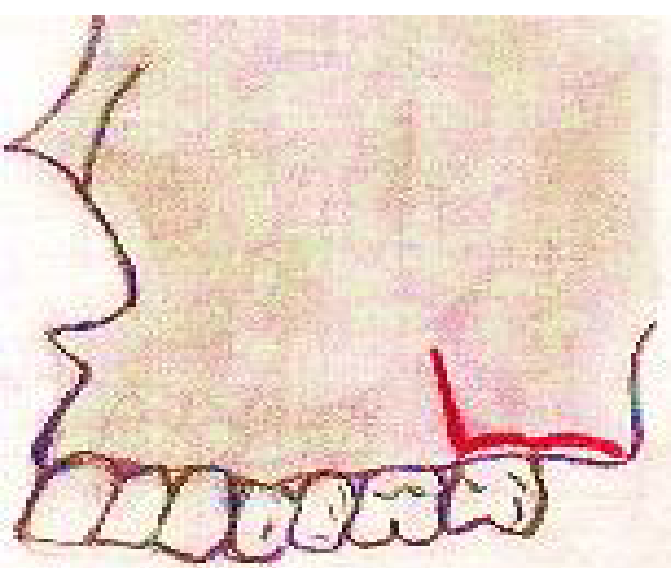

Figure 24: The design of the triangular incision for the maxilla.

period painful and inconfortable, damage at the level of the periodontal fibers to cervical insertion when performed the incision, the triangular flap has higher rate of edema and with better visibility operatory [128].

Sandhu et al. reported in their study comparing two types of flaps, the envelope flap dehiscence had higher inflammation and the bayonet ( Triangular) flap used to compare the effects of pain, swelling, trismus, wound dehiscence after extraction of impacted third molars, the degree of inflammation according to various authors is influenced by the degree of eruption (Partial or Total) and angulation, for them there was no difference and there was a very low incidence of inflammation of vertical molars compared with mesio-angle, the degree of inflammation was not related to the duration of the surgery [129] .

Arta et al., incision type has no effect on the second molar distal periodontal health, but may influence the primary wound healing and a degree of alveolar osteitis [130].

Martins et al, conducted a comparison of 2 types of flaps and found no significant differences relating to the second molar periodontal healing and consider other factors as are to be analyzed, patient age, area of contact between 2 and 3 molar pericoronal follicle size, presence of 
pre-existing periodontal inflammation, retention rate, amount of bone removed, amount of attached gingiva distal to 2 molar, proximity to the ramus of the mandible and type of suture and skill the professional $[111,131]$.

Erdogan et al., comparing 2 types of flap (Envelope and triangular) and the first has a lower degree of inflammation than the second, there is no significant difference in the degree of trismus between the two flaps, operative time, number of painkillers taken, recommende envelope flap to present inflamation lower rate [108].

Kırtıloğlu et al., comparing 2 types of flap (Szmyd and Triangular or Paramarginal) found no difference in healing, recommend surgical removal with minimal trauma and flap Szmyd a distal intact gingiva to the second molar and periodontal healing compared other flap after completely impacted molar extraction or mesioangular horizontal position [132].

Jakse et al., conclude that the envelope flap produces the flap

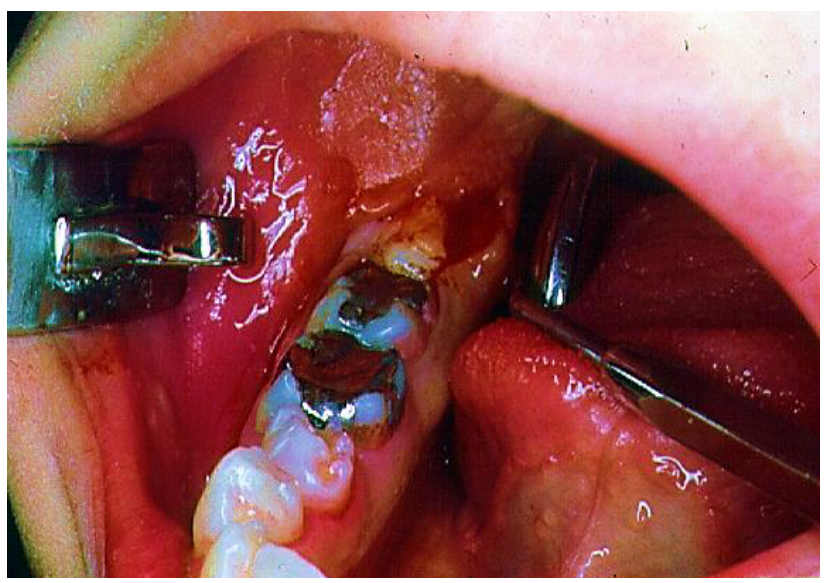

Figure 25: The design of the triangular incision for the jaw advocated by Marzola. The design of the triangular incision in the posterior mandible, with its withdrawal, and an oblique incision in the papilla distobuccal the second molar to the bottom groove (Marzola, 1975).

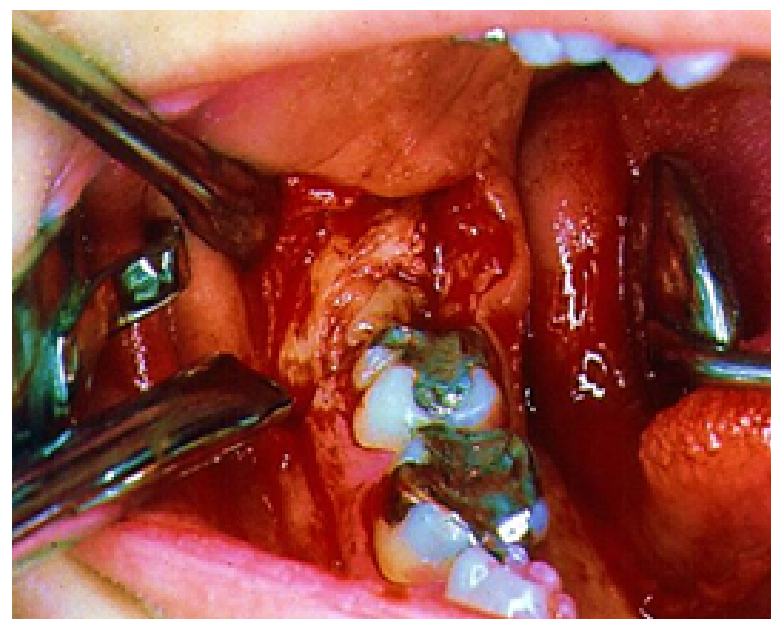

Figure 26: The design of the triangular incision (MARZOLA, 1975) for the jaw, after folding the flap providing an appropriate field for the surgeon without damaging the anatomy of the second molar.

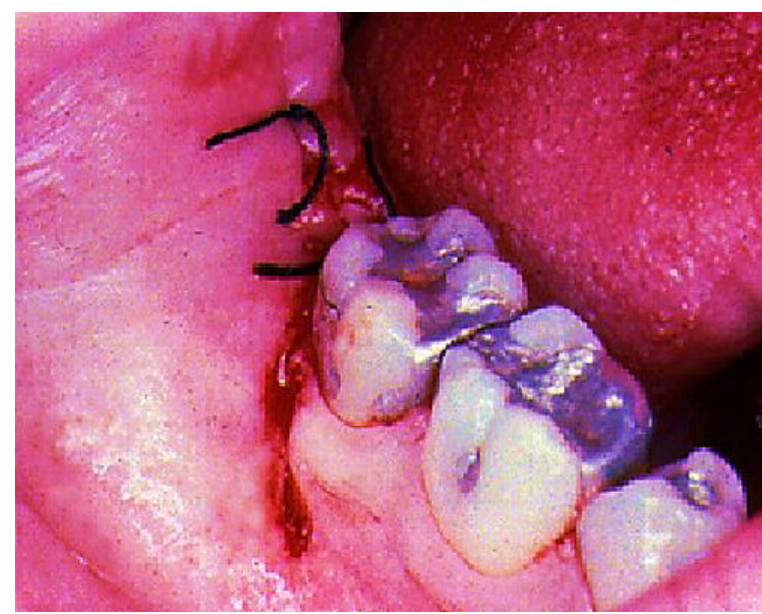

Figure 27: The design of the triangular incision (MARZOLA, 1975) for the jaw, after the folding of the flap ensures a sufficient field for the surgeon without damaging the anatomy of the second molar. The suture is then performed only on that portion where the triangle was removed, leaving open the oblique incision, functioning as a permanent drain in the first days after surgery, avoiding that dreaded swelling of the early days of this surgery.

dehiscence Szmyd and this affects the primary healing, this produces a long, painful and uncomfortable for the patient postoperatively [133].

Pasqualini et al., reported that the secondary closure after extraction of impacted third molars, provides results considering the variables of pain and inflammation, reducing postoperative discomfort and primary closure could be more painful and produce alveolar osteitis [134].

The design of the proposed incision in adherence to techniques Avellanal and a change could bring considerable changes in wound healing with positive with the success of the maneuver results. [99] The triangular incision posterior to the second molar facilitate the vision of the site and also access to the bone region, and a better location for the side that would serve as a natural site drainage oblique incision. This oblique incision was started at the angle distobuccal the second molar and descends to the bottom of the groove (Figures 25 and 26). This incision was sutured only oblique angle together with the back and would not be sewn to the bottom of the groove remaining open and working as a permanent drain in the first postoperative days (Figure 27). Excellent postoperative results were seen for these more than fifty years of observation [93].

\section{Discussion}

A variety of proposals for addressing incisions impacted third molars, are unclear but the findings of this work and tend to be controversial, many studies lack a small number of cases and variables under investigation could be exclusive, talks a lot about the experience of the surgeon to avoid complications, operative time, however all procedures reported complications as always, trismus, pain, swelling, difficulty in mouth opening, and others do not take into account factors such as quality of life of patients, affected significantly.

\section{Conclusion}

There are a variety of proposals to address incisions of impacted third molars, but the conclusions are not clear and these jobs tend to be controversial and many studies lack a small number of cases and 
variables under investigation may be unique, and much talk about the experience of the surgeon to avoid complications and operative times. However all procedures always report complications, trismus, pain, swelling, difficulty opening the mouth, and do not take into account other factors such as the quality of due patients, which was significantly affected.

1. The flaps do not present alterations distal to the second molar periodontal level 6 months after the extraction, so the flap design is a matter of individual preference of the surgeon, and the type of training received [108,123,126-128,130,135,136,137] many techniques require prior training to handle killer [123].

2. If there is a related problem with the soft tissues around the mandibular second molars, is apparently not a result of the surgery or the art, but is the result of another process. Further comparative studies are still needed to determine the best technique [125].

3. The type of flap does not diminish the effects, inflammation, pain and better mouth opening after extraction, the absence of increase in depth is not related to the type used flap is the result of a technical conservative [122-136].

4. The few studies that perform a comparison between different incision techniques do not find a significant difference on the adverse effects of third molar surgery regarding; periodontal attachment loss, plaque index, bone level distal to the second molar, gingival margin, periodontal probing depth, inflammation, pain, trismus, mouth opening, no significant differences can demonstrate that an incision should be used with preference on the other to improve the quality of life of patients [122-136].

\section{References}

1. Bouloux G, Steed M, Perciaccante V (2007) Complications of Third Molar Surgery. Oral Maxillofacial Surg Clin N Am 19: 117-128.

2. Amarillas E, Toranzo J, Martínez R, Loyola M, Hidalgo J, et al. (2010) Use of Therapeutic Laser After Surgical Removal of Impacted Lower Third Molars. J Oral Maxillofac Surg 68: 319-324.

3. Farish S, Bouloux G (2000) General Technique of Third Molar Removal. Oral Maxillofacial Surg Clin N Am 19: 23-43.

4. Susarla S, Dodson T (2007) Preoperative Computed Tomography Imaging in the Management of Impacted Mandibular Third Molars. J Oral Maxillofac Surg 65: 83-88.

5. Graziani F, D’Aiuto F, Arduino P, Tonelli M, Gabriele M (2006) Perioperative dexamethasone reduces post-surgical sequelae of wisdom tooth removal. A split mouth randomized double-masked clinical trial. Int JOral Maxillofac Surg 35: $241-246$

6. Adeyemo WL, James O, Ogunlewe MO, Ladeinde AL, Taiwo OA, et al. (2008) Indications for extraction of third molars: a review of 1763 cases. Niger Postgrad Med J 15: 42-46.

7. Susarla S, Blaese Br, Magalnick D (2003) Third molar surgery and associated complications. Oral Maxillofacial Surg Clin N Am 15: 177-186

8. Pozos A, Martínez R, Aguirre P, Pérez J (2007) Tramadol Administered in a Combination of Routes for Reducing Pain After Removal of an Impacted Mandibular Third Molar. J Oral Maxillofac Surg 65: 1633-1639.

9. Kirmeier R, Truschnegg A, Payer M, Acham S, Schulz K, et al. (2007) Evaluation of a muscle relaxant on sequelae of third molarsurgery: a pilot study. Oral Surg Oral Med Oral Pathol Oral Radiol Endod 104: e8-e14.

10. Blondeau F, Daniel N (2007) Extraction of Impacted Mandibular Third Molars: Postoperative Complications and Their Risk Factors. JCDA 73: 325

11. Abu-El Naaj I, Braun R, Leiser Y, Peled M (2010) Surgical Approach to Impacted Mandibular Third Molars-Operative Classification. J Oral Maxillofac Surg 68: 628-633.
12. Guillaume B, Lacoste JP, Gaborit N, Brossard G, Cruard A, et al. (2006) Microcomputed tomography used in the analysis of the morphology of root canals in extracted wisdom teeth. British Journal of Oral and Maxillofacial Surgery 44: 240-244.

13. Adeyemo WL (2006) Do pathologies associated with impacted lower third molars justify prophylactic removal? A critical review of the literature. Oral Surg Oral Med Oral Pathol Oral Radiol Endod 102: 448-52.

14. Wagner KW, Otten JE, Schoen R, Schmelzeisen R (2005) Pathological mandibular fractures following third molar removal. Int J Oral Maxillofac Surg 34: $722-726$.

15. Lübbers HT, Matthews F, Damerau G, Kruse AL, Obwegeser JA, et al. (2011) Anatomy of impacted lower third molars evaluated by computerized tomography: is there an indication for 3-dimensional imaging? Oral Surg Oral Med Oral Pathol Oral Radiol Endod 111: 547-550.

16. Kunkel M, Doz P, Morbach T, Kleis W, Wagner W (2006) Third molar complications requiring hospitalization. Oral Surg Oral Med Oral Pathol Oral Radiol Endod 102: 300-306.

17. Kim HR, Choi BH, Engelke W, Serrano D, Xuan F, et al. (2011) A comparative study on the extractions of partially impacted mandibular third molars with or without a buccal flap: a prospective study. J Oral Maxillofac Surg 69: 966-970.

18. Offenbacher S, Lieff S, Boggess KA, Murtha AP, Madianos PN, et al. (2001) Maternal periodontitis and prematurity. Part I: Obstetric outcome of prematurity and growth restriction. Ann Periodontol 6: 164-174.

19. White RP Jr, Madianos PN, Offenbacher S, Phillips C, Blakey GH, et al. (2002) Microbial complexes detected in the second/third molar region in patients with asymptomatic third molars. J Oral Maxillofac Surg 60: 1234-1240.

20. Flynn TR, Shanti RM, Levi MH, Adamo AK, Kraut RA, et al. (2006) Severe odontogenic infections, part 1: prospective report. J Oral Maxillofac Surg 64 1093-1103.

21. Flynn TR, Shanti RM, Hayes C (2006) Severe odontogenic infections, part 2 prospective outcomes study. J Oral Maxillofac Surg 64: 1104-1113.

22. Sánchez AR, Kupp LI, Sheridan PJ, Sánchez DR (2004) Maternal chronic infection as a risk factor in preterm low birth weight infants: the link with periodontal infection. J Int Acad Periodontol 6: 89-94.

23. Blakey GH, Marciani RD, Haug RH, Phillips C, Offenbacher S, et al. (2002) Periodontal pathology associated with asymptomatic third molars. J Ora Maxillofac Surg 60: 1227-1233.

24. White RP Jr, Offenbacher S, Phillips C, Haug RH, Blakey GH, et al. (2002) Inflammatory mediators and periodontitis in patients with asymptomatic third molars. J Oral Maxillofac Surg 60: 1241-1245.

25. White RP Jr, Offenbacher S, Blakey GH, Haug RH, Jacks MT, et al. (2006) Chronic oral inflammation and the progression of periodontal pathology in the third molar region. J Oral Maxillofac Surg. 2006; 64: 880-885.

26. Blakey GH, Jacks MT, Offenbacher S, Nance PE, Phillips C, et al. (2006) Progression of periodontal disease in the second/third molar region in subjects with asymptomatic third molars. J Oral Maxillofac Surg 64: 189-193.

27. Blakey GH, Parker DW, Hull DJ, White RP Jr, Offenbacher S, et al. (2009) Impact of removal of asymptomatic third molars on periodontal pathology. J Oral Maxillofac Surg 67: 245-250.

28. Rajasuo A, Sihvonen OJ, Peltola M, Meurman JH (2007) Periodontal pathogens in erupting third molars of periodontally healthy subjects. Int $\mathrm{J}$ Oral Maxillofac Surg 36: 818-821.

29. White RP Jr, Phillips C, Hull DJ, Offenbacher S, Blakey GH, et al. (2008) Risk markers for periodontal pathology over time in the third molar and non-third molar regions in young adults. Int J Oral Maxillofac Surg 66: 749-754.

30. Peltroche H, Reichhart E, Schmitt W, Lütticken R, Haase G (2000) Investigation of infectious organisms causing pericoronitis of the mandibular third molar. $J$ Oral Maxillofac Surg 58: 611-616

31. Sixou JL, Magaud C, Jolivet-Gougeon A, Cormier M, Bonnaure-Mallet M (2003) Evaluation of the mandibular third molar pericoronitis flora and its susceptibility to different antibiotics prescribed in france. J Clin Microbiol 41: 5794-5797.

32. Fuster MA, Gargallo J, Berini L, Gay C (2008) Evaluation of the indication for surgical extraction of third molars according to the oral surgeon and the primary care dentist. Med Oral Patol Oral Cir Bucal 13: E499-E504. 
33. Mohammed-Ali RI, Collyer J, Garg M (2010) Osteomyelitis of the mandible secondary to pericoronitis of an impacted third molar. Dent Update 2010; 37: 106-108.

34. Marciani RD (2007) Third Molar Removal: An Overview of Indications, Imaging, Evaluation, and Assessment of Risk. Oral Maxillofacial Surg Clin N Am 19: 1-13.

35. Kaushik SK, Gupta SK (2010) Impacted Third Molar Surgery and the Aviator. Ind J Aerospace Med 54: 26-31.

36. Chaparro A, Pérez S, Valmaseda E, Berini L, Gay C (2005) Morbidity of third molar extraction in patients between 12 and 18 years of age. Med Oral Patol Oral Cir Bucal 10: 422-431.

37. Ahmad N, Gelesko S, Shugars D, White RP Jr, Blakey G, et al. (2008) Caries experience and periodontal pathology in erupting third molars. J Oral Maxillofac Surg 66: 948-953.

38. Garaas R, Moss KL, Fisher EL, Wilson G, Offenbacher S, et al. (2011) Prevalence of visible third molars with caries experience or periodontal pathology in middleaged and older Americans. J Oral Maxillofac Surg 69: 463-470.

39. Fisher EL, Moss KL, Offenbacher S, Beck JD, White RP Jr (2010) Third molar caries experience in middle-aged and older Americans: a prevalence study. $J$ Oral Maxillofac Surg 68: 634-640.

40. Ozeç I, Hergüner Siso S, Taşdemir U, Ezirganli S, Göktolga G (2009) Prevalence and factors affecting the formation of second molar distal caries in a Turkish population. Int J Oral Maxillofac Surg. 2009; 38: 1279-1282.

41. Chang SW, Shin SY, Kum KY, Hong J (2009) Correlation study between distal caries in the mandibular second molar and the eruption status of the mandibula third molar in the Korean population. Oral Surg Oral Med Oral Pathol Oral Radiol Endod 108: 838-843.

42. McArdle LW, Renton TF (2006) Distal cervical caries in the mandibular second molar: an indication for the prophylactic removal of the third molar? $\mathrm{Br} \mathrm{J}$ Oral Maxillofac Surg 44: 42-45.

43. Shugars DA, Elter JR, Jacks MT, White RP, Phillips C, et al. (2005) Incidence of occlusal dental caries in asymptomatic third molars. J Oral Maxillofac Surg 63: $341-346$

44. Allen RT, Witherow H, Collyer J, Roper-Hall R, Nazir MA, et al. (2009) The mesioangular third molar--to extract or not to extract? Analysis of 776 consecutive third molars. Br Dent J 2009 Jun 13; 206: 586-587.

45. Yamaoka MM, Furusawa K, Ikeda M, Hasegawa T (1999) Root resorption of mandibular second molar teeth associated with the presence of the third molars. Australian Dental Journal 44: 112-116.

46. Nitzan D, Keren T, Marmary $Y$ (1981) Does an impacted tooth cause roo resoption of the adjacent one? Oral Surg 51: 221-224.

47. Bagheri S, Ali Khan H (2007) Extraction Versus Nonextraction Management of Third Molars. Oral Maxillofacial Surg Clin N Am 19: 15-21.

48. Sidlauskas A, Trakiniene G (2006) Effect of the lower third molars on the lower dental arch crowding. Stomatologija 8: 80-84.

49. Bernabé E, Flores C (2006) Dental morphology and crowding. A multivariate approach. Angle Orthod 76: 20-25.

50. Niedzielska I (2005) Third molar influence on dental arch crowding. Eur J Orthod 27: 518-523.

51. Harradine NW, Pearson MH, Toth B (1998) The effect of extraction of third molars on late lower incisor crowding: a randomized controlled trial. $\mathrm{Br} \mathrm{J}$ Orthod 25: 117-122.

52. Al-Balkhi KM (2004) The effect of different lower third molar conditions on the re-crowding of lower anterior teeth in the absence of tight interproximal contacts one-year post orthodontic treatment: a pilot study. J Contemp Dent Pract 5: 66-73.

53. Nance PE, White RP Jr, Offenbacher S, Phillips C, Blakey GH, et al. (2006) Change in third molar angulation and position in young adults and follow-up periodontal pathology. J Oral Maxillofac Surg 64: 424-428.

54. Grau V, Gargallo J, Almendros N, Gay C (2011) Mandibular fractures related to the surgical extraction of impacted lower third molars: a report of 11 cases. J Oral Maxillofac Surg 69: 1286-1290.

55. Al-Belasy FA, Tozoglu S, Ertas U (2009) Mastication and late mandibular fracture after surgery of impacted third molars associated with no gross pathology. J Oral Maxillofac Surg 67: 856-861.

56. Chrcanovic BR, Custódio AL (2010) Considerations of mandibular angle fractures during and after surgery for removal of third molars: a review of the literature. J Oral Maxillofac Surg 14: 71-80.

57. Libersa P, Roze D, Cachart T, Libersa JC (2002) Immediate and late mandibular fractures after third molar removal. J Oral Maxillofac Surg 60: 163-166.

58. Marquez IM, Stella JP (1998) Modification of sagittal split ramus osteotomy to avoid unfavorable fracture around impacted third molars. Int J Adult Orthodon Orthognath Surg 13: 183-187.

59. Santos S, Moreira R, Araújo M (2009) Treatment of a Mandibular Angle Fracture by Champy's Method after Removal of Contralateral Impacted Third Molar: Case Report. Rev Cir Traumatol Buco-Maxilo-fac Camaragibe 9: 15-20.

60. Bodner L, Brennan PA, McLeod NM (2011) Characteristics of iatrogenic mandibular fractures associated with tooth removal: review and analysis of 189 cases. Br JOral Maxillofac Surg 49: 567-572.

61. Stathopoulos P, Mezitis M, Kappatos C, Titsinides S, Stylogianni E (2011) Cysts and tumors associated with impacted third molars: is prophylactic removal justified? J Oral Maxillofac Surg 69: 405-408.

62. Jasinevicius TR, Pyle MA, Kohrs KJ, Majors JD, Wanosky LA. Prophylactic third molar extractions: US dental school departments' recommendations from 1998/99 to 2004/05. Quintessence Int. 2008; 39(2):165-176.

63. Adeyemo WL (2006) Do pathologies associated with impacted lower third molars justify prophylactic removal? A critical review of the literature. Oral Surg Oral Med Oral Pathol Oral Radiol Endod 102: 448-452.

64. Almendros N, Alaejos E, Quinteros M, Berini L, Gay C (2008) Factors influencing the prophylactic removal of asymptomatic impacted lower third molars. Int J Oral Maxillofac Surg 37: 29-35

65. Anderson M (1998) Removal of asymptomatic third molars: indications, contraindications, risks and benefits. J Indiana Dent Assoc 77: 41-46.

66. Song F, O'Meara S, Wilson P, Golder S, Kleijnen J (1999) The effectiveness and cost-effectiveness of prophylactic removal of wisdom teeth. Semin Orthod 5: 191-204.

67. Song F, Landes DP, Glenny AM, Sheldon TA (1997) Prophylactic removal of impacted third molars: an assessment of published reviews. Br Dent $\mathrm{J} 182$ 339-346.

68. Matevosyan NR (2011) Periodontal disease and perinatal outcomes. Arch Gynecol Obstet 283: 675-686.

69. Khader Y, Al-shishani L, Obeidat B, Khassawneh M, Burgan S, et al. (2009) Maternal periodontal status and preterm low birth weight delivery: a casecontrol study. Arch Gynecol Obstet 279: 165-169.

70. Sacco G, Carmagnola D, Abati S, Luglio PF, Ottolenghi L, et al. (2008) Periodontal disease and preterm birth relationship: a review of the literature. Minerva Stomatol 57: 233-250.

71. Pitiphat W, Joshipura KJ, Gillman MW, Williams PL, Douglass CW, et al. (2008) Maternal periodontitis and adverse pregnancy outcomes. Community Dent Oral Epidemiol 36: 3-11.

72. Siqueira FM, Cota LO, Costa JE, Haddad JP, Lana AM, et al. (2007) Intrauterine growth restriction, low birth weight, and preterm birth: adverse pregnancy outcomes and their association with maternal periodontitis. J Periodontol 78 : 2266-2276.

73. Toygar HU, Seydaoglu G, Kurklu S, Guzeldemir E, Arpak N (2007) Periodonta health and adverse pregnancy outcome in 3,576 Turkish women. J Periodonto 78: 2081-2094.

74. Sharma R, Maimanuku LR, Morse Z, Pack AR (2007)Preterm low birth weight associated with periodontal disease in the Fiji Islands. Int Dent J 57: 257-260.

75. Sánchez AR, Bagniewski S, Weaver AL, Vallejos N. Correlations between maternal periodontal conditions and preterm low birth weight infants. JInt Acad Periodontol 9: 34-41.

76. Madrid C, Bouferrache K, Pop S, Abarca M (2009) Is atherosclerosis a periodontally-induced disease? Rev Med Suisse 5: 2388-2393.

77. Kshirsagar AV, Moss KL, Elter JR, Beck JD, Offenbacher S, et al. (2005) 
Periodontal disease is associated with renal insufficiency in the Atherosclerosis Risk in Communities (ARIC) study. Am J Kidney Dis 45: 650-657.

78. Craig RG, Spittle MA, Levin NW (2002) Importance of periodontal disease in the kidney patient. Blood Purif 20: 113-119.

79. D'Aiuto F, Ready D, Tonetti MS (2004) Periodontal disease and C-reactive protein-associated cardiovascular risk. J Periodontal Res 39: 236-241.

80. D'Aiuto F, Parkar M, Andreou G, Brett PM, Ready D, et al. Periodontitis and atherogenesis: causal association or simple coincidence? J Clin Periodontol 31: 402-411.

81. Glurich I, Grossi S, Albini B, Ho A, Shah R et al. Systemic inflammation in cardiovascular and periodontal disease: comparative study. Clin Diagn Lab Immunol 9: 425-432.

82. Czerniuk MR, Górska R, Filipiak KJ, Opolski G (2004) Inflammatory response to acute coronary syndrome in patients with coexistent periodontal disease. J Periodontol 75: 1020-1026.

83. Abou-Raya S, Naeem A, Abou-El KH, El BS (2002) Coronary artery disease and periodontal disease: is there a link? Angiology 53: 141-148.

84. Aronow WS (2003) C-reactive protein. Should it be considered a coronary risk factor? Geriatrics 58: 19-22-25.

85. Katz J, Chaushu G, Sharabi Y (2001) On the association between hypercholesterolemia, cardiovascular disease and severe periodontal disease. $\mathrm{J}$ Clin Periodontol 28: 865-868.

86. Johnson C, Patel G, Messieha Z (2003) The relationship between coronary artery disease and periodontal disease. Dent Today 22: 100-105.

87. Beck JD, Slade G, Offenbacher S (2000) Oral disease, cardiovascular disease and systemic inflammation. Periodontol 23: 110-120.

88. Dye BA, Choudhary K, Shea S, Papapanou PN (2005) Serum antibodies to periodontal pathogens and markers of systemic inflammation. J Clin Periodontol 32: 1189-1199.

89. Blum A, Front E, Peleg A (2007) Periodontal care may improve systemic inflammation. Clin Invest Med 30: E114-117.

90. Doğan N, Orhan K, Günaydin Y, Köymen R, Okçu K, et al. (2007) Unerupted mandibular third molars: symptoms, associated pathologies, and indications for removal in a Turkish population. Quintessence Int 38: e497-e505.

91. Al-Khateeb TH, Bataineh AB (2006) Pathology associated with impacted mandibular third molars in a group of Jordanians. J Oral Maxillofac Surg 64: 1598-1602.

92. Mehra P, Castro V, Freitas RZ, Wolford LM (2001) Complications of the mandibular sagittal split ramus osteotomy associated with the presence or absence of third molars. J Oral Maxillofac Surg 59: 854-859.

93. Marzola C (2008) Fundamentos de Cirurgia Buco Maxilo Facial. São Paulo: Ed. Big Forms.

94. Fränzel W, Gerlach R, Hein HJ, Schaller HG (2006) Effect of tumor therapeutic irradiation on the mechanical properties of teeth tissue. Z Med Phys 16: 148-154.

95. Zadik Y, Levin L (2007) Decision Making of Israeli, East European, and South American Dental School Graduates in Third Molar Surgery: Is There a Difference? J Oral Maxillofac Surg 65: 658-662.

96. Guidance on the extraction of wisdom teeth. National Institute for Clinical Excellence (NICE) 2000.

97. Prophylactic Removal of Wisdom Teeth: A Review of the Clinical Benefit and Guidelines. Canadian Agency For Drygs And Technologies in Health. Health Technologiy Assessment HTA. August 2010.

98. Mettes DTG, Nienhuijs MMEL, van der Sanden WJM, Verdonschot EH, Plasschaert A (2005) Interventions for treating asymptomatic impacted wisdom teeth in adolescents and adults. Cochrane Database of Systematic Reviews ,Issue 2.

99. Friedman JW (2007) The Prophylactic Extraction of Third Molars: A Public Health Hazard. American Journal of Public Health 97: 1554-1559.

100. Jongh A, Olff M, Hoolwerff H, Aartman I, Broekman B, et al. (2008) Anxiety and post-traumatic stress symptoms following wisdom tooth removal. Behaviour Research and Therapy 46: 1305-1310.

101. Garip H, Abali O, Goker K, Gokturk U, Garip Y (2004) Anxiety and extraction of third molars in Turkish patients. Br J Oral Maxillofac Surg 42: 551-554.
102. Majid OW, Mahmood WK (2011) Effect of submucosal and intramuscular dexamethasone on postoperative sequelae after third molar surgery: comparative study. Br J Oral Maxillofac Surg 49: 647-652.

103. Barbosa NL, Thomé AC, Costa C, Oliveira J, Scariot R (2011) Factors associated with complications of removal of third molars: A trans $\neg$ versal study. Med Oral Patol Oral Cir Bucal 16: e376-380.

104. Gbotolorun OM, Olojede AC, Arotiba GT, Ladeinde AL, Akinwande JA, et al (2007) Impacted mandibular third molars: presentation and postoperative complications at the Lagos University Teaching Hospital. Nig Q J Hosp Med 17: 26-29.

105. Clauser B, Barone R, Briccoli L, Baleani A (2009) Complications in surgical removal of mandibular third molars. Minerva Stomatol 58: 359-366.

106. Akadiri OA, Okoje VN, Arotiba JT (2008) Identification of risk factors for shortterm morbidity in third molar surgery. Odontostomatol Trop 31: 5-10.

107. Almendros N, Berini L, Gay C (2006) Influence of lower third molar position on the incidence of preoperative complications. Oral Surg Oral Med Oral Patho Oral Radiol Endod 102: 725-732.

108. Erdogan Ö, Tatlı U, Üstün Y, Damlar I (2011) Influence of two different flap designs on the squeal of mandibular third molar surgery. Oral Maxillofac Surg 15: 147-152.

109. Mead SV (1930) Incidence of impacted teeth. Int Orthodont oral Surg Radio I16: 885-890.

110. Cogeswell WW (1933) Variations in normal anatomic struture. J Oral Sint Ass. 2: $1423-1427$

111. Avellanal CD (1946) Cirugía odontomaxilar. Buenos Aires Ed. Ediar.

112. Ward TG (1956) The split bone technique for removal of lower third molars Brit dent J 201: 297-304.

113. Maurel G (1959) Clinica y Cirugía maxilo-facial. Buenos Aires: Ed. Alfa.

114. Kruger GO (1959) Management of impactions. Dent Clin N Amer.

115. Ries Centeno GA (1960) El tercer molar inferior retenido. Buenos Aires: Ed. El Ateneo.

116. Szmyd L (1971) Impacted teeth. Dent Clin North Am 15: 299-318.

117. Berwick WA (1966) Alternative method of flap reflection. Br Dent J 121: 295-296.

118. Howe GL (1971) The management of impactedmandibular third molars. Minor oral surgery 2ed Bristol.

119. Lotter $R$ (1984) Periodontal considerations in the extracion of retained wision teeth varyng technics. Chir Dent; 252: 35-44.

120.Berzaghi, CM Curcio R (1989) Incisão em M.Revista da Ass. Paulista de Odontologia 43: 32-34.

121. Stevão EL, Azoubel E (1998) Técnica alternativa para remoção de terceiros molares submucosos e intra-ósseos da mandíbula $\mathrm{BCI}$ 5: 15-19.

122. Silva F, Cabral RJ, Felipe G, Machado E (2006) Incisions for third including lower molarInternational Journal Of Dentistry, Recife 1: 30-34.

123. Suarez M, Gutwald R, Reichman J, Otero X, Schmelzeisen R (2003) Margina flap versus paramarginal flap in impacted third molar surgery: A prospective study. Oral Surg Oral Med Oral Pathol Oral Radiol Endod 95: 403-408.

124. Nageshwar (2002) Comma Incision for Impacted Mandibular Third Molars. J Oral Maxillofac Surg 60: 1506-1509.

125. Cetinkaya B, Sumer M, Tutkun F, Sandikci E, Misir F (2009) Influence of different suturing techniques on periodontal health of the adjacent second molars after extraction of impacted mandibular third molars. Oral Surg Oral Med Oral Pathol Oral Radiol Endod 108: 156-161.

126. Rosa AL, Carneiro MG, Lavrador MA, Novaes AB Jr (2002) Influence of flap design on periodontal healing of second molars after extraction of impacted mandibular third molars. Oral Surg Oral Med Oral Pathol Oral Radiol Endod 93: 404-407.

127. Karaca I, Şimşek S, Uğar D, Bozkaya S (2007) Review of flap design influence on the health of the periodontium after mandibular third molar surgery. Oral Surg Oral Med Oral Pathol Oral Radiol Endod 104: 18-23.

128. Sanchis JM, Hernández S, Peñarrocha M (2008) Flap repositioning versus conventional suturing in third molar surgery. Med Oral Patol Oral Cir Bucal 13: E138-42. 
Citation: Blanco G, Lora D , Marzola C (2016) The Different Types of Flaps in the Surgical Relations of the Third Impacted Molars - Literature Review. Dentistry 7: 425. doi:10.4172/2161-1122.1000425

129. Kirk D, Liston P, Tong D, Love R (2007) Influence of two different flap designs on incidence of pain, swelling, trismus, and alveolar osteitis in the week following third molar surgery. Oral Surg Oral Med Oral Pathol Oral Radiol Endod 104: 1-6.

130. Sandhu A, S. Sandhu S, Kaur T (2010) Comparison of two different flap designs in the surgical removal of bilateral impacted mandibular third molars. Int JOral Maxillofac Surg 39: 1091-1096.

131. Arta SA, Kheyradin RP, Mesgarzadeh AH, Hassanbaglu B (2011) Comparison of the Influence of Two Flap Designs on Periodontal Healing after Surgical Extraction of Impacted Third Molars. J Dent Res Dent Clin Dent Prospects 5: $1-4$.

132. Martins L, Lemes $\mathrm{CH}$, Zardo M, Egg CM (2007) Evaluation of periodontal healing on the distal of lower second molars, using two types of flap designs for removal of impacted third molars.Publ. UEPG Biol. Health Sci Ponta Grossa 13: 73-80
133. Kırtıloğlu T, Bulut E, Sümer M, Cengiz I (2007) Comparison of 2 Flap Designs in the Periodontal Healing of Second Molars After Fully Impacted Mandibular Third Molar Extractions. J Oral Maxillofac Surg 65: 2206-2210.

134. Jakse N, Bankaoglu V, Wimmer G, Eskici A, Pertl C (2002) Primary wound healing after lower third molar surgery: Evaluation of 2 different flap designs. Oral Surg Oral Med Oral Pathol Oral Radiol Endod 93: 7-12.

135. Pasqualini D, Cocero N, Castella A, Mela L, Bracco P (2005) Primary and secondary closure of the surgical wound after removal of impacted mandibular third molars: a comparative study. Int JOral Maxillofac Surg 34: 52-57.

136. Infante $P$ (2009) Post-operative comparison of two flap designs in inferior third molar surgery. Rev Esp Cir Oral Maxilofac 31: 185-192.

137. Laissle G ,Aparicio P, Uribe F, Alcocer D (2009) Post-operative comparison of two flap designs in lower third molar surgery. Rev Esp Cir Oral Maxilofac 31: 185-192. 